Jurnal Professional FIS UNIVED Vol.1 No.1 Februari 2014

\title{
PENGARUH KOMUNIKASI ANTAR PRIBADI DAN KUALITAS PRODUK TERHADAP MOTIVASI KERJA \\ (Studi Kasus pada Multi Level Marketing Perusahaan Tianshi)
}

\author{
Oleh : \\ Dwi Kusuma Yuniarti \\ Staff Pengajar Prodi Ilmu Komunikasi Fakultas Ilmu Sosial UNIVED Bengkulu
}

\begin{abstract}
The rise of the networked enterprises, including the company Tianshi has made more than 4 million Indonesian listed as direct sales distributor. In doing this sale, face to face communication was very effective to changed attitudes, opinions and behavior of a person. This study was a quantitative and it had three variables: Variable X1 was interpersonal communication, Variable X2 was a quality product, and variable $Y$ was the motivation to work. From the research, it's known that the knowledge of the quality and benefits of a product would encourage other people (potential consumers) to buy a product. From the research, it could be concluded that there was a significant influence of interpersonal communication sponsor on the motivation to work among network members. This was due to the good relationship between sponsors and their members. Sponsors who were able to create a pleasant atmosphere as well as deliver interesting messages to the members would make the members understand any information submitted
\end{abstract}

Keywords: networked enterprises, interpersonal communication, working motivation, product quality

\section{PENDAHULUAN}

Komunikasi tatap muka sangat efektif untuk mengubah sikap, pendapat dan perilaku seseorang. Salah satu bentuk komunikasi tersebut adalah komunikasi antar pribadi, Menurut Rogers dalam Liliweri (1997:12), komunikasi antar pribadi merupakan komunikasi dari mulut ke mulut yang terjadi dalam interaksi tatap muka antara dua orang atau lebih. Dalam komunikasi ini, tanggapan komunikasi atas pesan komunikasi kepada anggotanya dapat diketahui reaksinya secara langsung. Seperti jika pimpinan mengetahui masalah anggotanya, maka ia akan bisa membantu memberikan solusi. Selain itu ia juga dapat memotivasi anggotanya tersebut untuk kembali bersemangat dalam bekerja, sehingga nantinya jaringan bisnis mereka akan semakin kuat. Liliweri (1994:123) mengemukakan bahwa semenjak berkembang berbagai karya tentang komunikasi antar pribadi, retorika hingga ke penelitian yang dilakukan oleh para psikologik, para ahli telah mengambil sikap untuk menjadikan komunikasi antar pribadi sebagai salah satu objek studinya. Kesimpulan yang bisa terlihat dari berbagai penelitian terdahulu menunjukkan bahwa komunikasi antar pribadi mempunyai hubungan erat dengan sikap dan perilaku.

Menurut data APLI (Asosiasi Penjualan Langsung Indonesia) hasil survey tahun 2000, lebih dari 4 juta orang Indonesia terdaftar sebagai distributor perusahaan- 
perusahaan penjualan langsung di Indonesia. Beberapa bagian diantaranya menjadi anggota jaringan perusahaan Tianshi. Sementara itu data jaringan bulan Juni 2010 menunjukkan bahwa anggota Tianshi di Bengkulu mencapai kurang lebih 1458 orang. Akan tetapi baru dua orang yang mampu mencapai posisi bintang 6. Selain itu dari ribuan orang tersebut tidak semuanya menjalankan bisnis ini dengan aktif. Itulah mengapa dikatakan membina sebuah jaringan agar bisa berkembang dengan sukses bukanlah pekerjaan yang mudah.

Motivasi seorang anggota jaringan untuk percaya dan yakin akan peluang bisnis Multi Level Marketing (MLM) dapat timbul karena dorongan dari dalam dan dari luar dirinya. Selain memberikan informasi mengenai peluang bisnis MLM, seorang senior dalam MLM yang dikenal dengan sponsor juga harus bisa menyakinkan anggota jaringannya tentang kualitas dari produk yang diproduksi oleh perusahaan, karena kepercayaan yang dimiliki oleh anggota jaringan terhadap kualitas produk yang diproduksi oleh perusahaan akan memberikan rasa percaya diri untuk menawarkan produk tersebut kepada orang lain.

Dari hasil pengamatan di lapangan terlihat bahwa bagian dari anggota jaringan perusahaan Tianshi melakukan juga mengkonsumsi terhadap produk-produk perusahaan. Artinya sebelum melakukan penawaran kepada konsumennya, mereka lebih dulu membuktikan kualitas dari produk tersebut. Dengan mempercayai kualitas produk tersebut maka motivasi mereka untuk menawarkan kepada orang lain sekaligus mengajak mereka bergabung dalam bisnis tersebut semakin tinggi. Adapun tujuan dari penelitian ini adalah untuk mengetahui pengaruh komunikasi antar pribadi terhadap motivasi kerja, serta untuk mengetahui pengaruh kualitas produk terhadap motivasi kerja.

\section{METODE PENELITIAN}

Penelitian ini bersifat kuantitatif dan didalamnya terdapat tiga variabel yaitu:

- Variabel $X_{1}$ adalah komunikasi antar pribadi

- Variabel $\mathrm{X}_{2}$ adalah kualitas produk

- Variabel Y adalah motivasi kerja

Adapun sampel yang digunakan dalam penelitian adalah sebanyak 94 orang. Teknik Pengumpulan Data yang digunakan antara lain kuesioner berjumlah 35 pertanyaan kepada responden yang merupakan sampel dalam penelitian ini. Wawancara untuk melengkapi dan memperjelas jawaban yang diberikan oleh responden melalui kuesioner maka peneliti akan mengadakan wawancara langsung dengan 10 orang responden. Observasi dalam penelitian dilakukan dengan observasi non partisipan dengan cara hanya mengamati objek yang akan diteliti tetapi tidak terlibat langsung. Contohnya ikut serta menghadiri pertemuan OPP (Open Plan Presentation) setiap minggu dan NDT (Network Development Training) setiap bulan.

\section{HASIL PENELITIAN DAN PEMBAHASAN}

\section{Pengaruh Komunikasi Antar pribadi Terhadap Motivasi Kerja}

Penelitian ini dilakukan dengan cara penyebarkan kuesioner terhadap 94 orang responden dengan jumlah item pertanyaan untuk variabel $\mathrm{X}_{1}$ sebanyak 11 pertanyaan.

Berdasarkan hasil perhitungan product moment untuk korelasi $\mathrm{X}_{1}$.Y diperoleh nilai 0,712 , kemudian hasil perhitungan tersebut dikonsultasikan dengan harga kritik $r(n=94)$ pada tabel product moment dengan taraf signifikan 5\% yang mempunyai nilai 0,202. Hasil konsultasi tersebut menunjukkan bahwah hasil $r_{x y}=0,712$ lebih besar daripada harga kritik $r=0,202$ dalam taraf signifikan $5 \%$. Dengan demikian konsultasi antar 
pribadi berpengaruh terhadap motivasi kerja. Hal ini mendukung hipotesis kerja dalam taraf signifikan.

Kemudian untuk mengetahui tinggi rendahnya tingkat signifikan antara komunikasi antar pribadi terhadap motivasi kerja. Hasil dari Ftest tersebut selanjutnya dikonsultasikan dengan harga kritik $\mathrm{r}$ pada $\mathrm{F}$ tabel $=3,94$, ternyata hasil perhitungan Ftes $=94,59$ jauh lebih besar dari $F$ tabel pada taraf signifikan 5\%. Hal ini menunjukkan bahwah komunikasi antar pribadi yang baik berpengaruh terhadap kerja anggota jaringan.

Berdasarkan hasil perhitungan product moment untuk korelasi $\mathrm{X}_{1}, \mathrm{Y}$, diperoleh nilai 0,712 . Hasil perhitungan ini menunjukkan signifikan setelah dikonsultasikan dengan harga titik $r \quad(n=94)$ pada tabel produk moment dalam taraf signifikan $5 \%$ yang mempunyai nilai 0,202. Hal ini membuktikan bahwa ada pengaruh komunikasi antar pribadi terhadap motivasi kerja. Sebagian besar responden merasa senang dengan suasana saat berkomunikasi dengan sponsornya. Suasana saat berkomunikasi dengan sponsornya menyenangkan. Komunikasi yang menyenangkan tersebut dapat menciptakan hubungan yang baik dan saling mempengaruhi diantara mereka, sehingga tercipta semangat untuk menjalankan bisnis Tianshi. Dari hasil wawancara terhadap 10 orang sponsor, sebagian besar dari mereka selalu berusaha untuk menciptakan suasana komunikasi yang menyenangkan dengan anggota jaringannya sehingga mereka merasa nyaman.

Dalam berkomunikasi, seorang sponsor juga harus memiliki kemampuan untuk mengemas pesan dan menyampaikannya dengan menarik. Berapa orang responden menyatakan bahwa cara sponsor menyampaikan informasi menarik perhatian mereka dan menimbulkan motivasi dalam diri mereka untuk menyampaikan kepada orang lain.

Dengan ketertarikan tersebut. Akhirnya mereka lebih mudah untuk menyerap informasi yang diberikan. Semakin banyak informasi yang dikuasai, mereka semakin percaya diri untuk menjalankan bisnis Tianshi. Beberapa orang sponsor juga mengemukakan pendapatnya. Bahwa memang harus mampu menyampaikan informasi menarik. Jika informasi disampaikan dengan kaku dan membosankan maka tidak akan mampu menimbulkan motivasi bagi yang mendengarkannya.

Suatu informasi akan mudah diterima apabila disertai antara keterbukaan antara sponsor dan anggotanya. Keterbukaan tersebut membuat anggota merasa bebas dan tidak mempunyai jarak. Sponsor secara terbuka bersedia berbagi informasi dan pengalaman yang dimilikinya. Sehingga anggota semakin bertambah pengetahuan terhadap bisnis Tianshi. Akan akan 20 orang responden atau 21,28\% menyatakan raguragu terhadap keterbukaan sponsor. Hal tersebut dikarenakan beberapa orang sponsor dalam menyampaikan informasi hanya terbatas mengenai bisnis Tianshi dan tidak ingin berbagi pengalaman dengan anggota jaringannya. Bisanya sponsor mempunyai alasan tersendiri untuk hal tersebut, akan tetapi beberapa anggota menganggapnya sebagai bentuk kurangnya keterbuakaan.

Selain berkomunikasi secara terbuka, sponsor juga harus memberikan perhatian atau berempati kepada anggotanya. Perhatian tersebut terutama diberikan terhadap perkembangan bisnis anggotanya. Hal tersebut senada dengan pendapat para sponsor. Beberapa orang diantara mereka mengemukakan bahwah mereka selalu memberikan perhatian kepada para anggotanya. Misalnya dengan selalu berusaha mendengarkan keluhan dan 
masalah yang dihadapi mereka serta berusaha membantu mencari jalan keluarnya. Hal tersebut dilakukan agar tidak menghambat motivasi kerja mereka, karena menurut pengalaman beberapa orang sponsor, kadang-kadang terdapat anggota jaringan yang tidak pernah menceritakan kendala dan masalah dalam menjalankan bisnis Tianshi. Akan tetapi, tidak lama kemudian mereka meninggalkan bisnis tersebut. Oleh karena itulah perhatian yang diberikan sponsor sangat penting bagi motivasi anggotanya.

Hal lain yang juga penting dimiliki seorang sponsor selain keterbukaan adalah dukungan. Dukungan tersebut diwujudkan dalam bentuk pemberian nasehat, saran dan kritik serta pujian apabila anggota mencapai sebuah prestasi. Beberapa sponsor pada saat diwawancara mengemukakan bahwah mereka selalu berupaya mendukung kemajuan prestasi para anggotanya. Hal tersebut dilakukan misalnya dengan cara memberikan strategi cepat untuk mencapai kesuksesan dalam bisnis Tianshi atau hal-hal lain yang berguna bagi kemajuan bisnis mereka. Akan tetapi, beberapa orang sponsor terkadang tidak berusaha bantu anggotannya namun juga tidak membiarkan mereka berjalan sendiri. Artinya sponsor terkadang tidak selalu ada saat anggota memerlukan hal itulah yang membuat anggota ragu-ragu terhadap dukungan sponsornya.

Begitu banyak kendala dalam menjalankan bisnis MLM kadangkala membuat para anggota merasa kurang bersemangat, bahkan kadang-kadang berfikir untuk meninggalkan bisnis tersebut. Apalagi dengan semakin menjamurnya bisnis Multi Level Marketing yang menawarkan bonus dan fasilitas yang lebih besar membuat anggota kadang-kadang merasa tertarik untuk mencoba. Situasi seperti itu harus bisa dihadapi secara bijaksana oleh sponsor.
Sponsor sering membina rasa kesamaan dengan mereka beberapa orang sponsor kadang-kadang merasa berkuasa terhadap anggotanya, terutama sponsor yang mempunyai posisi yang cukup tinggi. Sponsor tersebut biasanya mempunyai ambisi yang tinggi untuk mencapai kesuksesan sehingga terkadang cenderung untuk menekan dan memaksa anggotanya bekerja lebih keras lagi. Hal tersebut membuat anggota merasa dianggap sebagai bawahan, padahal mereka mempunyai kedudukan yang setara.

Suatu komunikasi antar pribadi yang baik juga terlihat pada interaksi yang terjalin diantara kedua belah pihak. Interaksi yang rutin dilakukan antara sponsor dan anggotanya akan menyebkan timbulnya kedekatan dan kesamaan diantara mereka. Sponsor mempunyai perasaan positif terhadap mereka. Hal tersebut berarti sponsor selalu menanamkan rasa percaya terhadap anggotanya tanpa mempunyai pikiran yang negatif. Perasaan tersebut membuat anggota merasa nyaman dan tenang dalam menjalankan bisnisnya. Akan tetapi, adakalanya ketika bisnis yang dijalankan anggota sedangkan vakum untuk beberapa waktu, sponsor bisa mengerti, namun terkadang juga bisa curiga anggotanya berniat untuk berhenti atau beralih ke bisnis MLM lain. Hal itulah yang membuat mereka meragukan perasaan positif sponsornya.

Selain perasaan positif, seorang sponsor juga harus selalu menanamkan rasa kesamaan dengan anggotanya. Hal tersebut penting karena jika anggota merasa memiliki kedudukan yang setara dengan sponsornya, maka tidak akan menjadi kesenjangan sosial diantara mereka. Anggota tidak akan merasa sebagai bawahan dan sponsor juga tidak akan menganggap dirinya sebagai batasan, karena dalam bisnis MLM hal tersebut tidak berlaku. 
Interaksi yang rutin dilakukan mempunyai peran yang penting, karena melalui hal tersebut seorang sponsor bisa selalu memantau perkembangan bisnis anggotanya. Karena itu jika seorang anggota mengalami penurunan semangat, seorang sponsor bisa slalu memantau perkembangan bisnis anggotanya. Karena itu jika seorang mengalami penurunan semangat, seorang sponsor bisa membantu membangkitkan kembali motivasi untuk kerja.

Hal lain yang juga penting dalam menciptakan komunikasi antar pribadi yang baik antara sponsor dan anggota jaringannya adalah koherasi. Koherasi yang dimaksud adalah terciptanya suatu benang merah atau jalinan diantara pesan-pesan yang disampaikan informasi atau pesan harus jelas dan sesuai dengan yang dihadapi oleh anggota, sehingga tercapai satu pengertian diantara keduanya. Kesesuaian antara pesan yang disampaikan sponsor dengan pemahaman mereka. Dengan kesesuaian tersebut serta didukung pula oleh faktorfaktor lain yang telah diuraikan di atas, terlihat bahwah motivasi kerja dalam dari anggota jaringan MLM Tianshi dapat menimbulkan melalui komunikasi yang antar pribadi yang baik dari sponsornya.

\section{Pengaruh Kualitas Produk Terhadap Motivasi Kerja}

Peneliti dilakukan dengan cara menyebarkan kuesioner terhadap 94 orang responden dengan jumlah item pernyataan untuk variabel $\mathrm{X}_{2}$ sebanyak 6 pertanyaan dari variabel $Y$ sebanyak 11 pertanyaan.

Berdasarkan hasil perhitungan product moment untuk korelasi $\mathrm{X}_{2} \quad \mathrm{y}$ diperoleh nilai 0,548, kemudian hasil perhitungan tersebut dikonsultasikan dengan harga kritik $\mathrm{r}(\mathrm{N}=94)$ pada tabel product moment dengan taraf signifikan $5 \%$ yang mempunyai nilai 0,202. Hasil konsultasi tersebut menunjukkan bahwah hasil rxy = 0,548 lebih besar dari harga kritik $r=0,202$ dalam taraf signifikan 5\%. Dengan demikian kualitas produk berpengaruh terhadap motivasi kerja. Hal ini mendukung hipotesis kerja dalam taraf signifikan.

Kemudian untuk mengetahui tinggi rendahnya tingkat signifikan antara kualitas produk terhadap motivasi kerja. Hasil dari $\mathrm{F}$ test tersebut selanjutnya dikonsultasikan dengan harga kritik pada $\mathrm{F}$ tabel $=3,94$, teryata hasil perhitungan $\mathrm{F}$ test $=39,48$ jauh lebih besar dari $\mathrm{F}$ tabel pada taraf signifikan $5 \%$. Hal ini menunjukkan bahwah kualitas produk berpengaruh terhadap motivasi kerja anggota jaringan.

\section{Pengaruh Kualitas Produk Terhadap Motivasi Kerja}

Dari hasil perhitungan produk moment untuk korelasi $\mathrm{X}_{2, .} \mathrm{Y}$, diperoleh nilai 0,548 kemudian hasil tersebut dikonsultasikan dengan harga kritik $r(\mathrm{~N}=94)$ pada tabel produk moment dengan taraf signifikan 5\% yang mempunyai nilai lebih besar dari harga kritik 0,2,2. Hal ini membuktikan bahwah terdapat pengaruh antara kualitas poduk terhadap motivasi kerja.

Untuk memperjelas pernyataan diatas, bagian besar responden menjawab bahwah produk-produk Tianshi berkualitas dan mereka merasa puas terhadap produk tersebut.

\section{Pengaruh Komunikasi Antarpribaadi Dan Kualitas Produk Terhadap Motivasi Kerja}

Dari uraian diatas telah diketahui bahwa terdapat pengaruh antara komunikasi antar pribadi terhadap motivasi kerja dan terdapat pengaruh antara kualitas produk terhadap motivasi kerja. Selain itu juga terdapat pengaruh antara komunikasi antar pribadi dan kualitas produk terhadap motivasi kerja. Hal itu dikarenakan dalam memberikan pemahaman mengenai kualitas dari produk-produk yang diproduksi oleh 
Perusahaan Tianshi, seorang sponsor selalu menyampaikan secara menarik dan menyenangkan sehingga anggota bisa menyerap informasi tersebut dengan baik. Pemahaman terhadap informasi membuat anggota meransang percaya diri dan termotivasi untuk menyampaikan kepada orang lain.

Pengetahuan terhadap kualitas dan manfaat dari suatu produk akan mendorong orang lain (calon konsumen) untuk membeli suatu produk. Keinginan tersebut membuat anggota jaringan yang memperkenalkan menjadi bersemangat. Kemampuan komunikasi yang baik juga dibutuhkan pada saat melakukan presentasi. Dalam pertemuan seperti OPP (Open Plan Presention), seorang sponsor akan memberikan pemaparan kepada peserta mengenai segala hal yang berhubungan dengan perusahaan Tianshi, termasuk produk-produknya. Jika sponsor tersebut mampu membangkitkan kepercayaan anggota terhadap produk tersebut, apalagi didukung oleh kesaksian dan pengalaman yang baik, maka akan membuat anggota rajin untuk menghadiri pertemuan tersebut, yang berarti juga telah timbul motivasi kerja dalam dirinya.

\section{PENUTUP}

\section{Kesimpulan}

Penelitian ini bertujuan untuk mengetahui pengaruh komunikasi antar pribadi dan kualitas produk terhadap motivasi kerja anggota jaringan. Adapaun yang menjadi objek penelitian adalah 94 orang anggota jaringan Tianshi yang ada di Bengkulu. Berdasarkan hasil uji statistic data penelitian, dapat ditarik beberapa kesimpulan adanya pengaruh antara komunikasi antar pribadi sponsor terhadap motivasi kerja anggota jaringan. Hal ini disebabkan adanya hubungan yang baik antara sponsor dan anggotanya. Sponsor yang mampu menciptakan suasana yang menyenangkan serta mengemas pesan dan menyampaikan secara menarik kepada para anggotanya akan membuat mereka memahami setiap informasi yang disampaikan. Di samping itu, dukungan dan empati dari sponsor pada saat berkomunikasi yang diikuti oleh perasaan positif juga bisa membangkitkan semangat anggota jaringan untuk bekerja. Faktor lain yang juga penting untuk mendukung keberhasilan suatu komunikasi antar pribadi adalah penanaman rasa kesamaan kedudukan dalam jaringan, melakukan interaksi secara rutin serta menyampaikan pesan secara baik dan koheren sehingga mampu membangkitkan motivasi kerja dalam diri anggota jaringan. Adanya pengaruh kualitas produk terhadap motivasi kerja anggota jaringan. Hal ini disebabkan karena suatu produk berkualitas yang dibuktikan dari manfaat, daya tahan, jaminan terhadap kerusakan. Kesesuaian antara harga dengan kualitasnya serta kemampuan produk tersebut dalam memberikan kepuasan bagi orang yang mengkonsumsinya, membuat anggota jaringan merasa percaya diri untuk memperkenalkan sekaligus menjualnya kepada konsumen, sehingga menimbulkan motivasi kerja dalam diri anggota jaringan tersebut. Adanya pengaruh komunikasi antar pribadi dan kualitas produk terhadap motivasi kerja. Hal tersebut disebabkan suatu komunikasi yang baik yang digunakan dalam menyampaikan informasi mengenai kualitas suatu produk, akan membuat anggota merasa mengetahui dengan baik informasi dan yakin terhadap produk tersebut. Hal itulah yang menimbulkan motivasi kerja dalam diri anggota untuk menyampaikan dan menawarkannya kepada orang lain. 


\section{Saran}

Berdasarkan hasil penelitian mengenai pengaruh komunikasi antar pribadi sponsor dan kualitas kerja anggota jaringan Tianshi di Bengkulu, maka ada beberapa saran yang penulis kemukakan yaitu: Seorang sponsor hendaknya meningkatkan hubungan yang baik dengan anggota jaringannya. Jika dalam menjalankan bisnis terdapat masalah atau kendala, sebaiknya dikonsultasikan bersama agar tidak menghambat pekerjaan. Hendaknya seorang sponsor selalu memantau setiap perkembangan dalam bisnis yang dijalankan anggota jaringannya agar mereka termotivasi untuk bekerja.

\section{DAFTAR PUSTAKA}

Arikunto, Suharsimi.1998. Prosedur Penelitian. Reneka cipta. Jakarta

Axinantio, Yoes. 1996. Multi Level Marketing \& Mail Order. CV. Gunung mas. Perkalongan.

Charmicael, allen. 1996. Network \& Multi Level Marketing. Pustaka Delapratasa Jakarta

Effendi, anong uchana. 2003. Ilmu Komunikasi, Teori Dan Praktek. Remaja Rosdakarya. Bandung

Komunikasi. Remaja rosda karya. Bandung

Effendi, Usman dan Praja, Juhaya.1984. Pengantar Psikologi. Angkasa Bandung

Hadi, Sutrisno.1993. Statistic 2. Andi offset. Yogyakarta

Kartono, Kartin. 1985. Psikologi Social Untuk Manajemen, Perusahaan Dan Industry. CV Rajawali. Jakarta
Liliweri, Alo. 1997. Komunikasi Antar Pribadi. Citra aditya bakti. Bandung.

--------------, 1994. Perspektif Tioritis Komunikasi Antar Pribadi. Remaja rosda karya. Bandung

Moekijat, 1990. Pengembangan Manajemen dan Motivasi. CV. Pioner jaya. Bandung

Prawirosantoso, suryadi. 2000. Manajemen Operasional Analisis Dan Studi Kasus, Edisi Kedua. Bumi aksara. Jakarta.

Roller, David 1995. Menjadi Kaya Dengan Multi Level Marketing. PT. Gramedia pustaka Utama. Jakarta.

Ruslan, Rosady. 2003. Metode Penelitian Public Relations dan Komunikasi. PT. Raja Graind. Jakarta

Sardiman, AM. 1994. Interaksi Motivasi Belajar dan Manajemen. CV remaja bandung

Siahaan. 1991. Komunikasi Pemasaran dan Penerapan. Pt. Bpk Gunung Mulia. Jakarta

Singarimbun, Masri. 1995. Motede Penelitian Survey. LP3ES. Jakarta

Siswanto, Bedjo. 1990. Manajemen Modern (Konsep Dan Aplikasi). Sinar Baru Bandung.

Swasta, Basu dan Irawan. 1997. Manajemen Pemasaran Modern. Edisi ke V. Liberty. Jakarta

Vincent. Gasperz. 1997. Manajemen Kualitas, Penerapan Konsep Kusalitas Dalam Manajemen Bisnis Total.Gramedia.Jakarta. 


\section{LAMPIRAN}

Tabel 1. Pengaruh Komunikasi Antar Pribadi Terhadap Motivasi Kerja

\begin{tabular}{|l|l|l|l|l|l|l|l|l|l|l|l|l|l|l|}
\hline \multirow{2}{*}{$\begin{array}{l}\text { Komunikasi } \\
\text { antar pribadi }\end{array}$} & \multicolumn{9}{l|}{ Motivasi Kerja } \\
\cline { 2 - 16 } & $\begin{array}{l}\text { Sangat } \\
\text { tinggi }\end{array}$ & \multicolumn{2}{l|}{ Tinggi } & \multicolumn{2}{l|}{ Sedang } & \multicolumn{2}{l|}{ rendah } & \multicolumn{2}{l|}{$\begin{array}{l}\text { Sangat } \\
\text { Rendah }\end{array}$} & \multicolumn{2}{l|}{ total } \\
\hline $\begin{array}{l}\text { Sangat } \\
\text { Tinggi }\end{array}$ & 11 & 11,70 & 9 & 9,58 & 2 & 2,13 & - & - & - & - & 22 & 23,41 \\
\hline Tinggi & 25 & 26,59 & 34 & 36,17 & 2 & 2,13 & - & - & - & - & 61 & 64,88 \\
\hline Sedang & 1 & 1,06 & 3 & 3,19 & - & - & - & - & - & - & 4 & 4,26 \\
\hline Rendah & - & - & - & - & - & - & 4 & 4,26 & 1 & 1,06 & 5 & 5,32 \\
\hline $\begin{array}{l}\text { Sangat } \\
\text { Rendah }\end{array}$ & - & - & - & - & - & - & 2 & 2,13 & - & - & 2 & 2,13 \\
\hline Jumlah & 37 & 39,35 & 46 & 48,94 & 4 & 4,26 & 6 & 6,38 & 1 & 1,06 & 94 & $100 \%$ \\
\hline
\end{tabular}

Tabel 2. Pengaruh Kualitas Produk Terhadap Motivasi Kerja

\begin{tabular}{|c|c|c|c|c|c|c|c|c|c|c|c|c|}
\hline \multirow{3}{*}{$\begin{array}{l}\text { Kualitas } \\
\text { Produk } \\
\text { Sangat Tinggi }\end{array}$} & \multicolumn{10}{|c|}{ Motivasi Kerja } & \multirow{2}{*}{\multicolumn{2}{|c|}{ Total }} \\
\hline & \multicolumn{2}{|c|}{$\begin{array}{l}\text { Sangat } \\
\text { tinggi }\end{array}$} & \multicolumn{2}{|c|}{ Tinggi } & \multicolumn{2}{|c|}{ Sedang } & \multicolumn{2}{|c|}{ Rendah } & \multicolumn{2}{|c|}{$\begin{array}{l}\text { Sangat } \\
\text { rendah }\end{array}$} & & \\
\hline & 18 & 19,15 & 25 & 26,60 & 1 & 1,06 & 1 & 1,06 & - & - & 45 & 47,87 \\
\hline Tinggi & 14 & 14,90 & 23 & 24,47 & 1 & 1,06 & - & - & - & - & 38 & 40,43 \\
\hline Sedang & 3 & 3,19 & - & - & 1 & 1,06 & 2 & 2,13 & & & 6 & 6,38 \\
\hline Rendah & - & - & - & - & 1 & 1,06 & 2 & 2,13 & & & 3 & 3,19 \\
\hline Sangat Rendah & - & - & - & - & - & - & 1 & 1,06 & 1 & 1,06 & 2 & 2,13 \\
\hline Jumlah & 35 & 37,24 & 48 & 51,07 & 4 & 4,26 & 6 & 6,38 & 1 & 1,06 & 94 & $100 \%$ \\
\hline
\end{tabular}

